\title{
The Impact of Natural Calcium Carbonate and Ubiquinone on Bone Mineral Density in Rabbits
}

\author{
Ahmed A. Hussein ${ }^{1}$ and Ghada A. Taqa ${ }^{2}$ \\ ${ }^{1}$ Ministry Of Health, Nineveh Health Directorate, Mosul, Iraq. \\ ${ }^{2}$ Department of Dental Basic Sciences, College of Dentistry, University of Mosul , Mosul , Iraq. \\ *Corresponding Author, Ghada A. Taqa, E-Mail: ghadataqa@ uomosul.edu.iq
}

\section{ABSTRACT}

This study investigates the effect of Ubiquinone and/or calcium carbonate $\left(\mathrm{CaCO}_{3}\right)$ on bone mineral density (BMD) in rabbits at the healing site in mandibular bone postoperatively. Sixty healthy white male New Zealand rabbits (almost the same age [5-6 months], weight [2.0 $\pm 0.25 \mathrm{~kg}]$ and circumstance) were used in this study. The heavy-duty dental engine drilled a mandibular groove of $2 \mathrm{~mm}$ diameter and $6 \mathrm{~mm}$ length in all animals. Postsurgery, the rabbits were randomly divided into six groups (10 each) according to the treatment. According to the evaluation period, each group was further subdivided into two subgroups (5 rabbits each); 15 and 30 days. The groups included; control group (the groove was not filled by anything) and treated groups which included five groups as follows: group I (in which the groove was filled with Ubiquinone), group II (groove was filled with $\mathrm{CaCO}_{3}$ ), group III (groove was filled with $\mathrm{CaCO}_{3}$ : Ubiquinone as a ratio [1:1]), group IV ( groove was filled with $\mathrm{CaCO}_{3}$ : Ubiquinone as a ratio [1:2]) and group $\mathrm{V}$ (groove was filled with $\mathrm{CaCO} 3$ : Ubiquinone as a ratio [2:1]). The BMD was measured using Densitometry after 15 and 30 days. Statistical analysis showed significant differences at $\mathrm{p} \leq 0.05$ in bone mineral density (BMD) between the control group $(92 \pm 0.15)$ and all other treated groups except group III $(125 \pm 3.54)$ and group IV (126 \pm 5.13$)$ showed no significant differences at follow-up times at 15 days. Also, in the present study, we found there is a significant difference in bone mineral density among the control group $(109 \pm 1.25)$, group I $(144 \pm 3.45)$, group II $(153 \pm 6.24)$ and group V $(182 \pm 12.56)$ groups respectively. ANOVA test

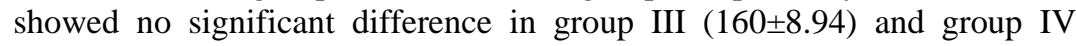
$(165 \pm 9.11)$ at follow-up times at 30 days. Adding the Ubiquinone and/or $\mathrm{CaCO}_{3}$ showed a significant increase in BMD manifested by bone healing like space-filling, newly formed bone trabeculae and a high number of lacunas compared with the control group. It can be concluded that, the Addition of Ubiquinone and/or $\mathrm{CaCO}_{3}$ to the mandibular fracture has a favourable effect on BMD and enhance bone healing in rabbits.
\end{abstract}

Keywords: Bone healing, Bone Mineral Density, CaCO3, Rabbits, Ubiquinone.

\section{INTRODUCTION}

The bone is a hard organ that is part of the vertebrate skeleton. Bones assist and protect the body's various organs, manufacture red and white blood cells, store minerals, provide structure and support to the body, and allow mobility. Bones come in a variety of shapes and sizes, with a complicated internal and external structure. They are lightweight but powerful and tough to use, and they perform a variety of functions. (Krousouloudi, 2019).
Original Article:

DOI:https://dx.doi.org/10.21608/javs .2021 .87062 .1091

Received :21 July, 2021.

Accepted :23 August, 2021.

Published in October, 2021.

This is an open access article under the term of the Creative Commons Attribution 4.0 (CC BY) International License . To view a copy of this license, visit:

http://creativecommons.org/licenses/by/4.0/ an organic component called ossein, mainly collagen, with an inorganic bone-mineral component comprising many salts(Bigham et al., 2020). Bone tissue is classified into two types: cortical bone and cancellous bone(Hunt et al., 2021). A bone defect is a lack of bone tissue that can occur as a result of an injury, sickness, inflammation, congenital or traumatic process in the same portion of the body. It can also happen as a result of continuing illnesses or surgical operations in some situations (Walsh et al., 2021). 


\section{The impact of natural calcium carbonate .........}

Ubiquinone or coenzyme Q10 is a substance similar to vitamins that is naturally oily-soluble in most eukaryotic cells. It's a 1.4-benzoquinone molecular subunit with a quinone chemical and 10 isoprenyls on the tail (Dawood et al., 2020). Ubiquinone is an important component of the electron transport (ETC) aerobic energy production cycle through the ADP to ATP transition (Knapp-Wilson et al., 2021). Because of the largest energy need, Ubiquinone is present in organs like the heart, liver and kidney at the highest concentration (Lu et al., 2020). It is found mostly in mitochondria because of its position in the electron transport chain and its interaction with reactive oxygen species (ROS) (Wang et al., 2021). Ubiquinone should be considered in 2 forms: oxidized (Ubiquinone) and reduced (ubiquinol) (Fullerton et al., 2020).

Calcium carbonate is a chemical substance having the formula $\mathrm{CaCO} 3$. It is a natural substance found in rocks such as calcite and aragonite minerals (most notably calcite, a form of sedimentary rock composed mostly of calcite). It is the major component of eggs, snail shells, seashells, and pearls (Barth and Jean, 2020). It is used in medicine as calcium or antacid supplement, but too much can be hazardous and induce bad digestion (Lattey et al., 2021).

As the basic module, an eggshell as a natural calcium carbonate supply is extremely important in bone metabolism and growth, particularly bone substitution. Studies have demonstrated that using eggshells as a bone replacement material is a promising and cost-effective option (Abdollahiyan et al., 2021). A variety of procedures and materials were used to correct osseous abnormalities in order to find a suitable alternative to autologous bone. Autologous bone augmentation is the preferred method and, consequently, gold standard (El-Gindy et al., 2021).

Bone mineral density (BMD), is the amount of bone mineral in bone tissue. Bone density is measured as the mass of minerals per volume of bone in clinical medicine as an indirect predictor of osteoporosis and fracture risk. It is measured using a technique known as Densitometry. The procedure is painless and noninvasive, with minimal radiation exposure (Cole, 2008). There is an association between poor bone density and a higher probability of fracture. The aim of the study was to evaluate the effects of $\mathrm{CaCO}_{3}$ and Ubiquinone on bone formation in rabbits by measuring BMD changes when the drug is given in therapeutic doses for different follow-up periods.

\section{MATERIIALS AND METHODS}

In this study, sixty healthy white male New Zealand rabbits weighing $2.0 \pm 0.25 \mathrm{~kg}$, aged (5-6) months were used. The animals were housed under laboratory conditions at a temperature $(23 \pm 2){ }^{\circ} \mathrm{C}$ with natural light/ dark cycle and fed with a standard diet, vegetables, crushed wheat, corn, and water during the experimental period. The habitant of the animal during the experiment was in a special cage in the animal house of the College of Dentistry, University of Mosul. This research was performed under the guidelines of the institutional animal research ethics committee of REC reference no. UoM.Dent/A.L.38/21 at 20/4/2021.

\section{Preparation of Calcium carbonate from the eggshell:}

The chicken eggshell used in this study was bought from local markets. Egg casings were removed and then the cover was lifted from the peel lining and then washed very well to ensure that the cover lining was removed and dried(Al-Abdali et al., 2015). 100 gram of eggshells were crushed by coffee grinder(Isa et al., 2020) and purification by special mash $(100 \mu \mathrm{m})$; To produce fine crystals, the crushed eggshells were added to $100 \mathrm{~mL}$ of distilled water and filtered by (No.6) Whatman filter paper. These were dried and sterilized by autoclave for one hour at $125^{\circ} \mathrm{C}$ and finally, calcium carbonate crystals white powder was produced. The Calcium carbonate crystals were combined with Ubiquinone in different proportional as following $\mathrm{CaCO}_{3}$ : ubiquinone ratio: $(0: 1,1: 0,1: 1,1: 2$, 2:1) W/W respectively.

\section{Experimental protocol:}

Randomly selected animals were assigned to six experimental groups (10 rabbits each). General anesthesia was achieved using an intramuscular injection of Xylazine $\mathrm{HCl}$ (Interchemie werken "De Adelaar" BV, Holland $(5 \mathrm{mg} / \mathrm{kg})$ and Ketamine hydrochloride (Romvac Company, SA)(40 mg $/ \mathrm{kg}$ )(Ahirwar et al., 2021). Complete anesthesia had been obtained within 5 minutes and lasted for about 50 minutes.

The hair was shaved from the operation site in the right mandibular region, and the skin was cleaned by povidone-iodine. Rabbits were placed in the left lateral position and a $5 \mathrm{~cm}$ longitudinal skin incision was made on the anterio-lateral aspect of the mandibular area. The mandibular muscles were displaced by forceps to expose the bone. A groove of $2 \mathrm{~mm}$ diameter and $6 \mathrm{~mm}$ length groove was drilled by bone drill and irrigation with saline solution to reduce the heat. Each group was further subdivided according to the medication period into two subgroups $(15,30$ days) (5 rabbits each)) as follow:

Control group: No treatment was received in the groove.

Treated groups were subdivided into:

Group I: the groove was filled with Ubiquinone.

Group II: the groove was filled with $\mathrm{CaCo}_{3}$.

Group III: the groove was filled with $\mathrm{CaCo}_{3}$ : Ubiquinone as a ratio (1:1). 


\section{Ahmed A. Hussein and Ghada A. Taqa}

Group IV: the groove was filled with $\mathrm{CaCo}_{3}$ : Ubiquinone as a ratio $(1: 2)$.

Group V: the groove was filled with $\mathrm{CaCo}_{3}$ : Ubiquinone as a ratio $(2: 1)$.

The muscles were sutured with absorbable suture material and the skin wound was closed with a black silk suture(china). The wounds were disinfected with $2 \%$ iodine solution and for five days following surgery, a veterinary antibiotic comprising (0.5g) Oxytetracycline was administered IM once daily.

\section{Radiographical analysis of bone densitometry:}

The digital Densitometric Kodak software 9000C (kodak9000three-dimensional-3D) Imaging system was used to calculate bone density in the region of interest (Mandibular Region at the defect location in the right mandible of rabbit). The equipment measured the distance between two points as a linear distance, and the readings provided the average value of bone density at every particular point(Taneja et al., 2015).

So, we obtained the information on the rate of bone formation and determined the variation in radiodensity between radiographs. Digital panoramic radiographs were made for all groups of rabbits at the time (15, 30 days) employing Kodiak 9000C 3D Extraoral Imaging System, V shape child jaw size, at $60 \mathrm{kv}, 2.0 \mathrm{~mA}, 13 \mathrm{sec}$ After complete anesthesia was obtained, the position of the rabbit's head was standardized. The rabbit was put on a small box and its ears were fixed on the system. A laser beam was adjusted in a manner parallel to the mandibular plain of the mandible bone of the rabbit (Fig. 1).

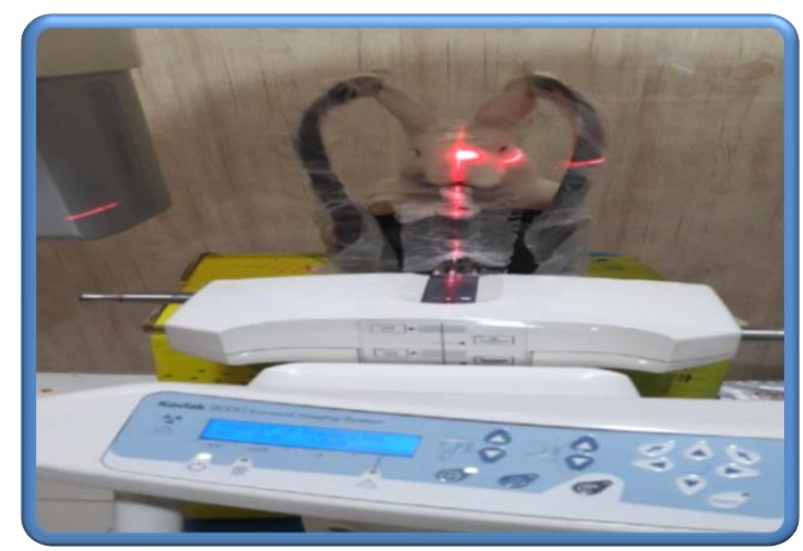

Fig.1: Densitometric analysis with orthopantomography (OPG) for mandible bone of rabbits.

\section{Statistical analysis:}

All data were processed and analyzed by the use of the statistical package SPSS ver. 25 (SPSS Inc., Chicago, ILL). ANOVA test was used to compare the differences in mean bone density among six study groups and different follow-up periods (Ali and
Bhaskar, 2016). A p-value $\leq 0.05$ was considered statistically significant.

\section{BMD results}

\section{RESULTS}

T-test showed a significant difference in BMD between the control group and all treated groups after 15 and 30 days of study. (Fig. 2).

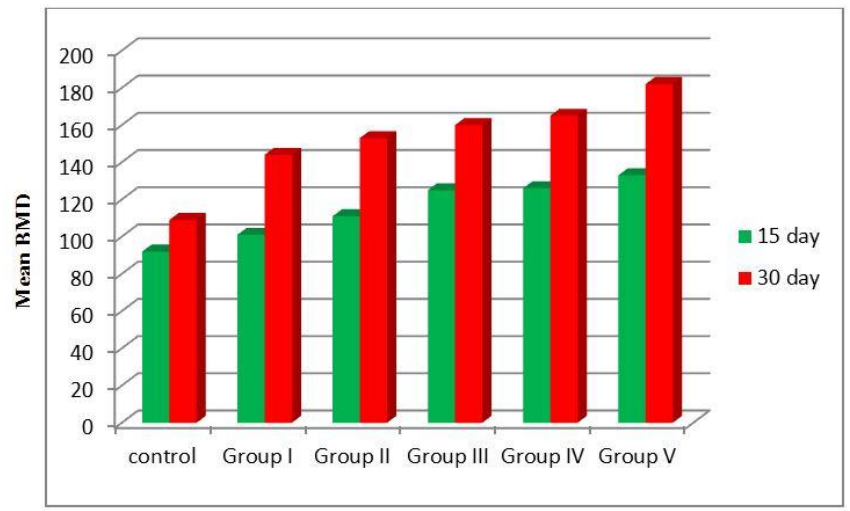

Fig. 2: Changes in BMD among control and treated groups at different follow-up periods.

After 15 days, statistical analysis showed significant differences at $\mathrm{p} \leq 0.05$ in BMD between the control group (92 \pm 0.15$)$ and all treated groups except group III (125 \pm 3.54$)$ and group IV (126 \pm 5.13$)$, which showed no significant differences ( $p>0.05$ ). (Table 1$)$. (Figures;3A [control group] ,4A [group I] ,5A [group II] ,6A [group III] ,7A [group IV] and 8A [group V]).

After 30 days, statistical analysis showed significant differences at $\mathrm{p} \leq 0.05$ in $\mathrm{BMD}$ among the control group (109 \pm 1.25$)$, group I (144 \pm 3.45$)$, group II $(153 \pm 6.24)$ and group V $(182 \pm 12.56)$. ANOVA test showed no significant difference in group III $(160 \pm 8.94)$ and group IV $(165 \pm 9.11)$ at follow-up times at 30 days (Table 1).(Figures;3B[control group],4B[group I],5B[group II],6B[group III],7B[group IV],8B[group V]).

Table 1: Comparison of BMD $(\mathrm{g} / \mathrm{cm} 2)$ among all study groups at 15 and 30 days.

\begin{tabular}{|lll|}
\hline Groups & BMD at day 15 & BMD at day 30 \\
\hline Control & $92 \pm 0.15^{\mathrm{A}}$ & $109 \pm 1.25^{\mathrm{A}}$ \\
Group I & $101 \pm 1.05^{\mathrm{B}}$ & $144 \pm 3.45^{\mathrm{B}}$ \\
Group II & $111 \pm 2.23^{\mathrm{C}}$ & $153 \pm 6.24^{\mathrm{C}}$ \\
Group III & $125 \pm 3.54^{\mathrm{D}}$ & $160 \pm 8.94^{\mathrm{D}}$ \\
Group IV & $126 \pm 5.13^{\mathrm{D}}$ & $165 \pm 9.11^{\mathrm{D}}$ \\
Group V & $133 \pm 6.29^{\mathrm{E}}$ & $182 \pm 12.56^{\mathrm{E}}$ \\
\hline
\end{tabular}

Different letters mean significant difference, at $\mathrm{P} \leq 0.05$. 


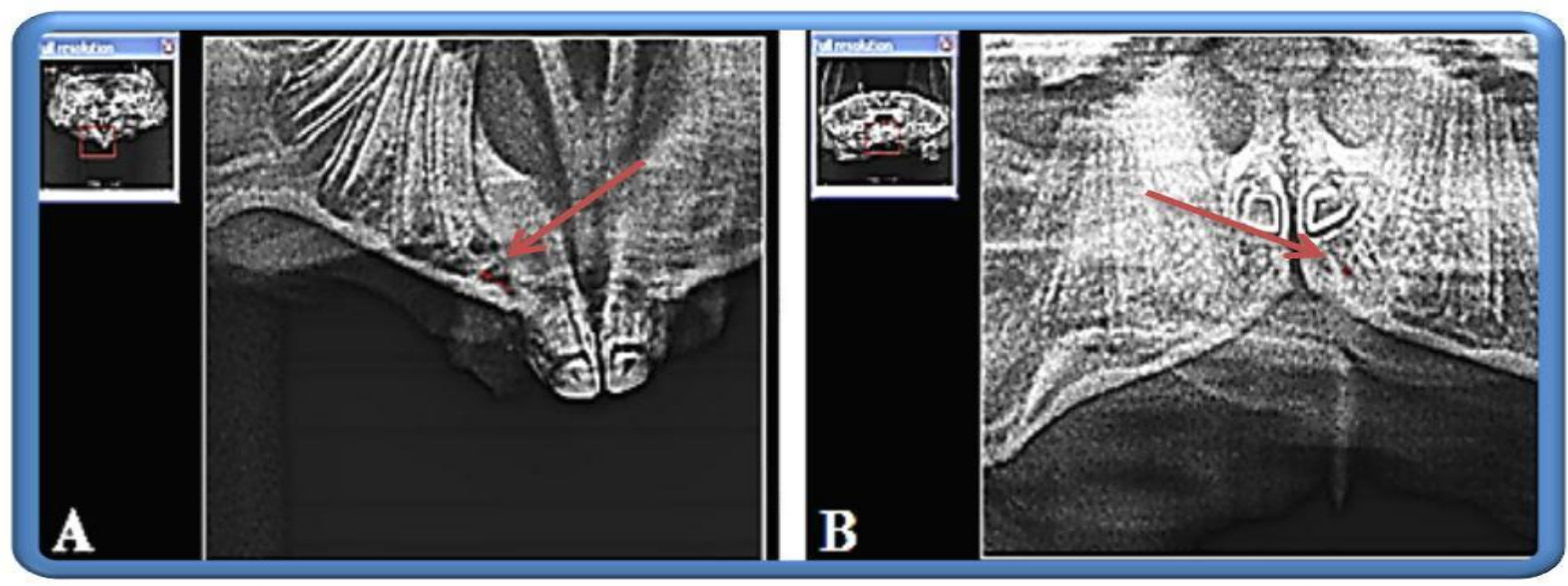

Fig. 3: A. Densitometric analysis for control rabbit group at day 15; B. Densitometric analysis for control rabbit group at day $30,(\longrightarrow)$ site of operation.

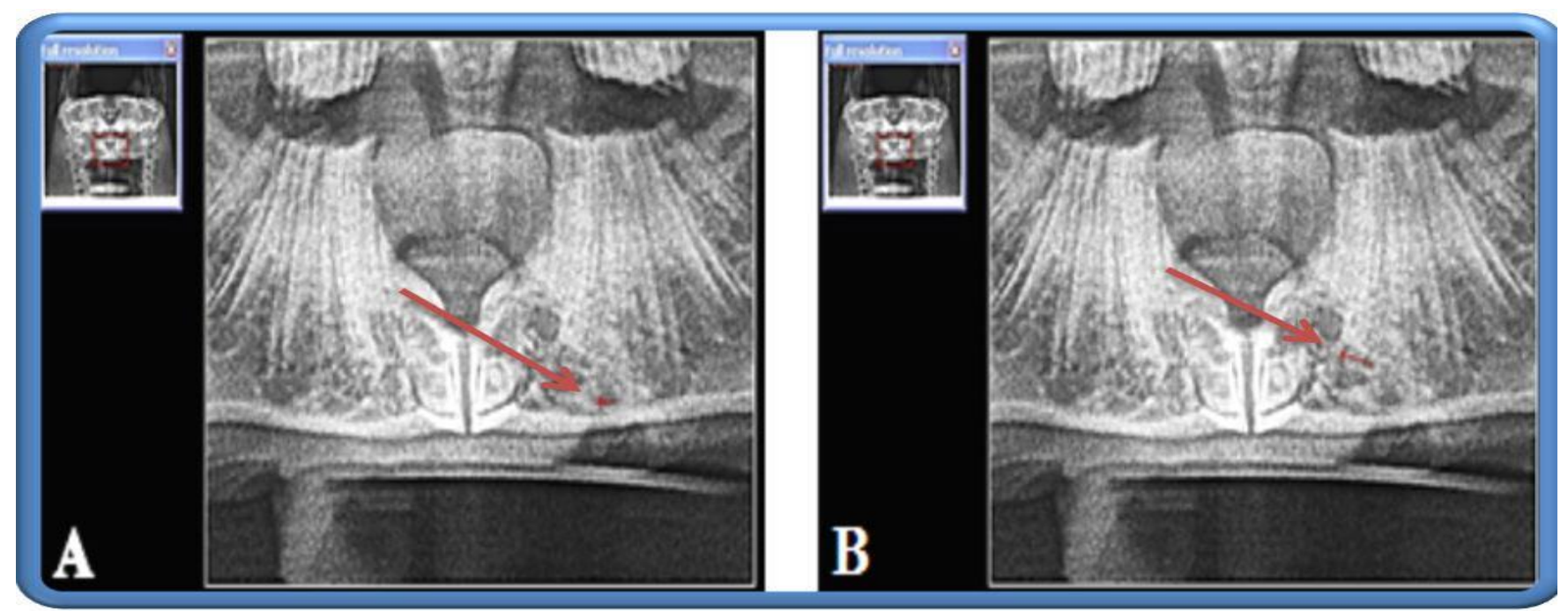

Fig. 4: A. Densitometric analysis for rabbit group I on day 15; B. Densitometric analysis for rabbit group I on day 30, ( $\longrightarrow)$ site of operation.

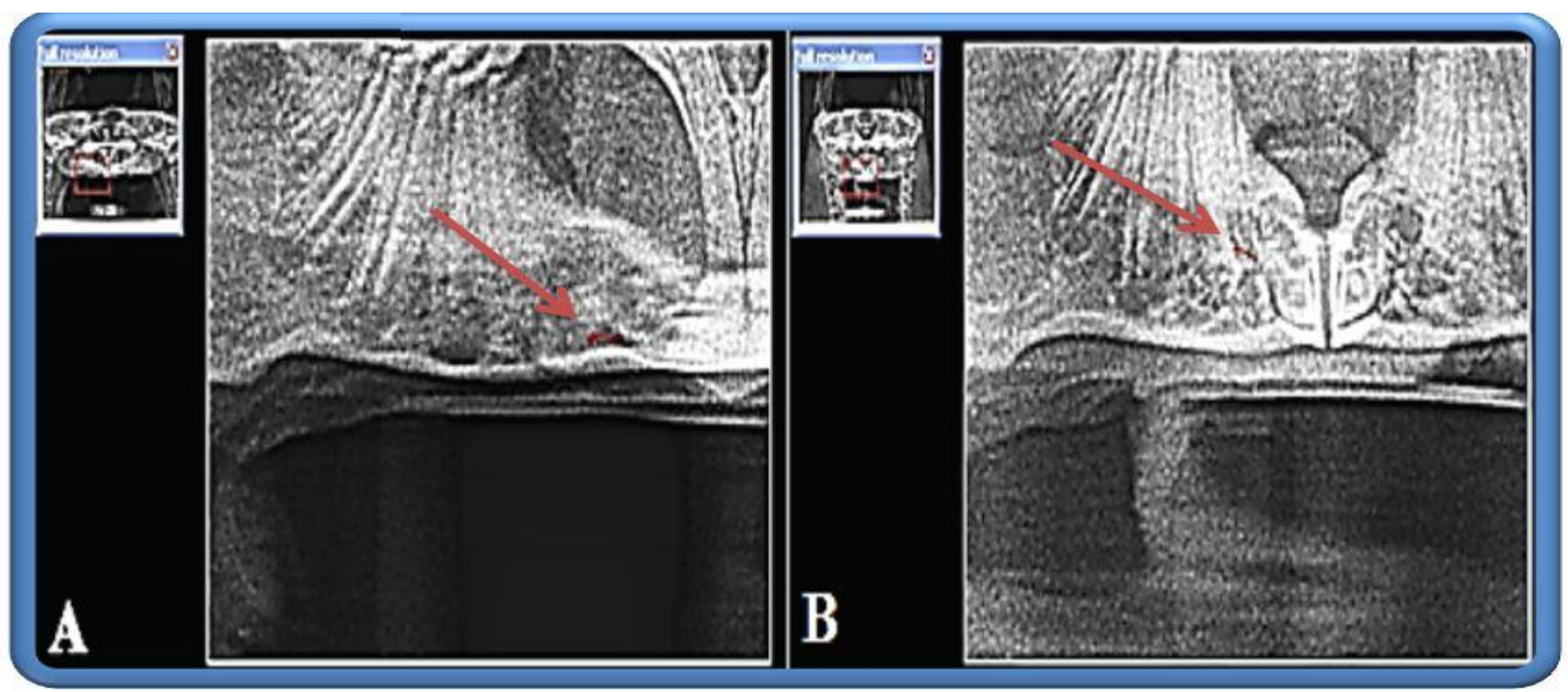

Fig. 5: A. Densitometric analysis for rabbit group II at day 15; B. Densitometric analysis for rabbit group II at day $30,(\longrightarrow)$ site of operation. 


\section{Ahmed A. Hussein and Ghada A. Taqa}

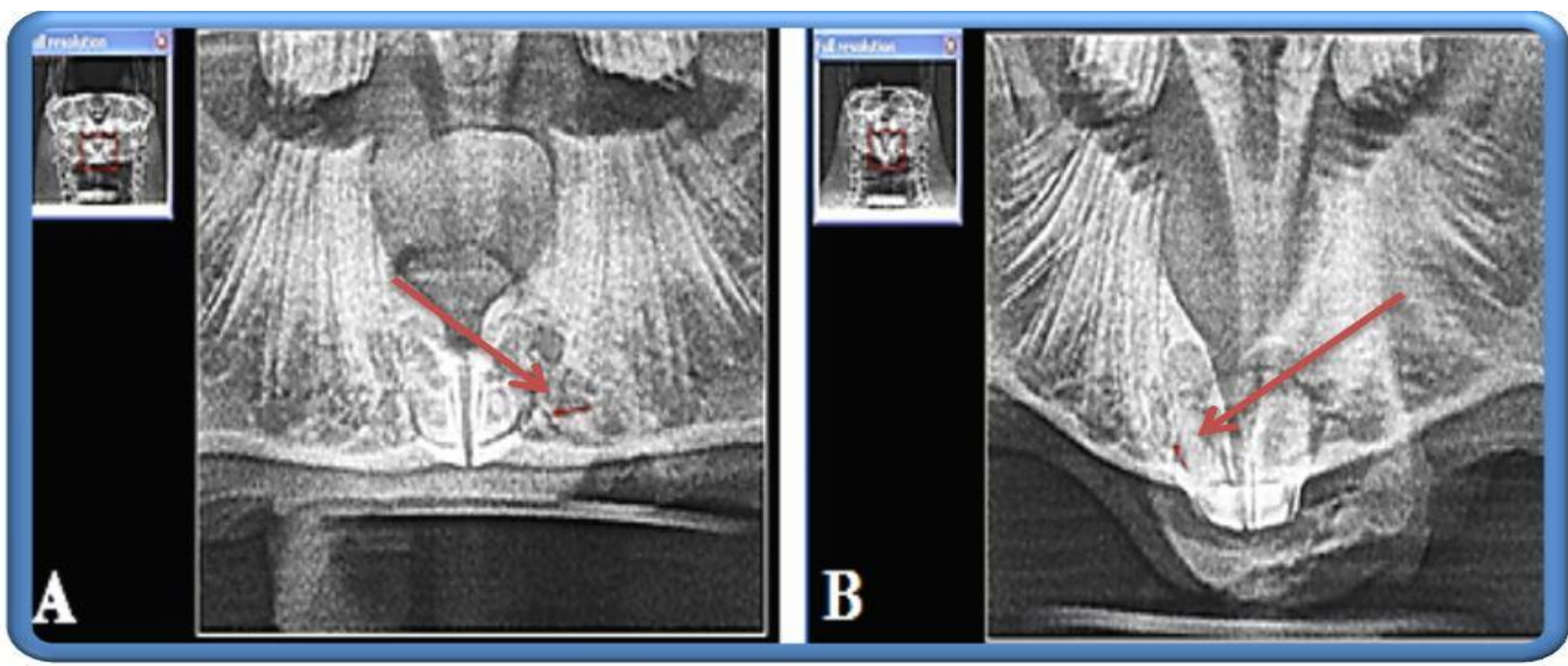

Fig. 6: A. Densitometric analysis for rabbit group III at day 15; B. Densitometric analysis for rabbit group III at day $30,(\longrightarrow)$ site of operation.

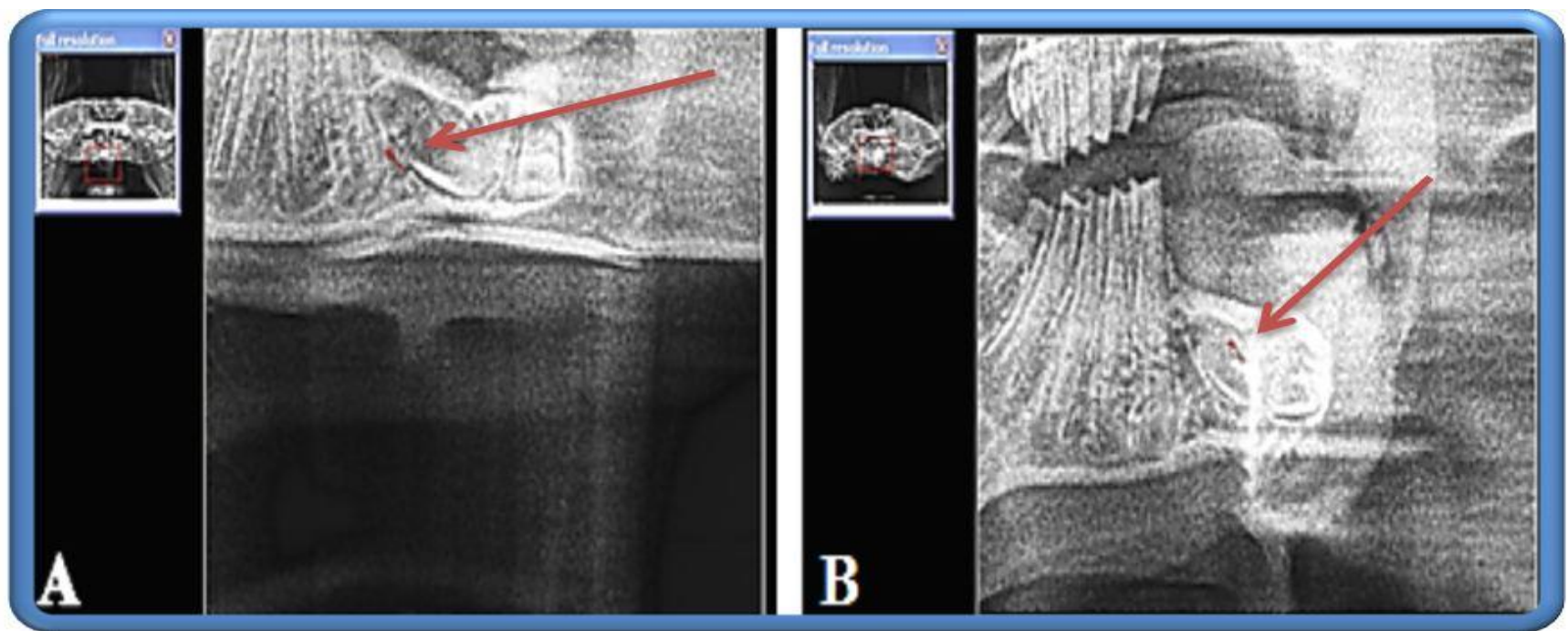

Fig. 7: A. Densitometric analysis for rabbit group IV at day 15; B. Densitometric analysis for rabbit group IV at day 30 , $(\longrightarrow)$ site of operation.

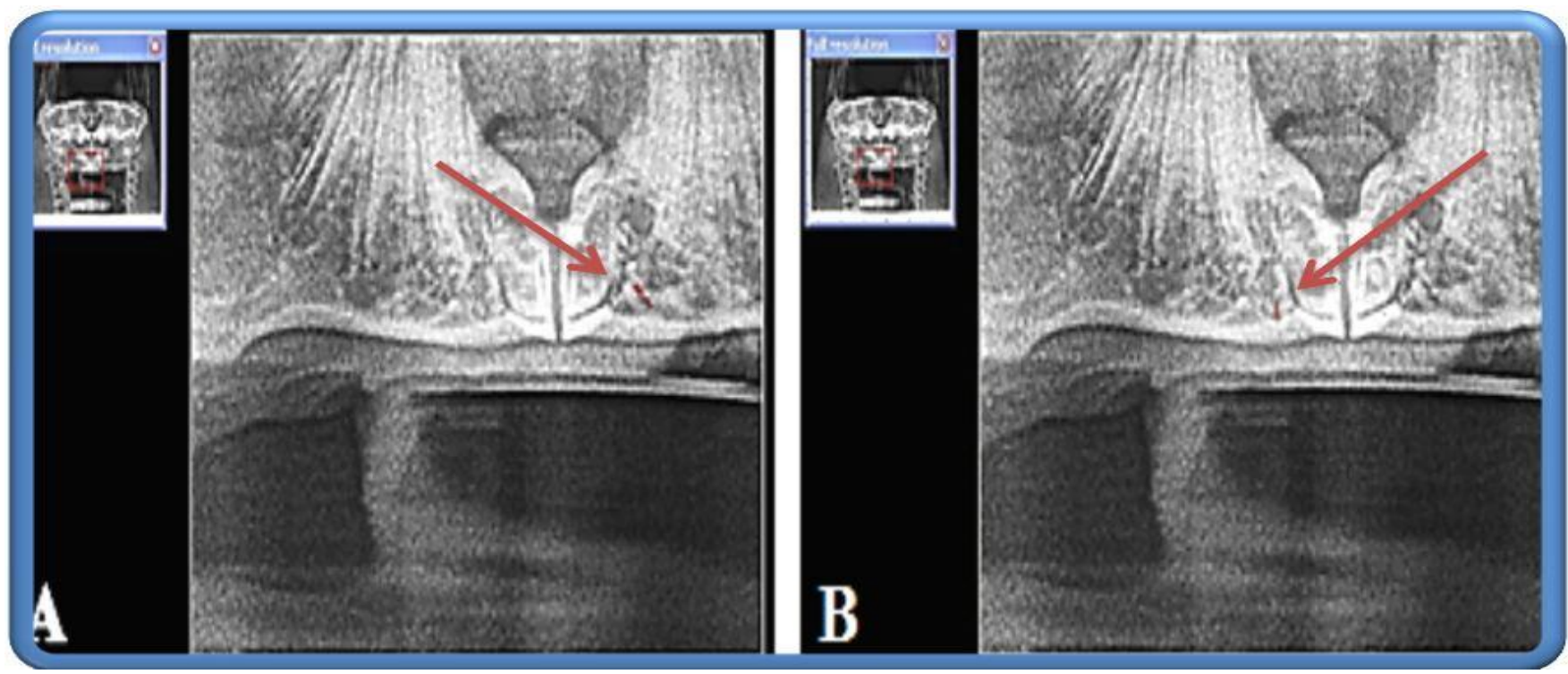

Fig. 8: A. Densitometric analysis for rabbit group V at day 15; B. Densitometric analysis for rabbit group V at day $30,(\longrightarrow)$ site of operation. 


\section{DISCUSSION}

When the bone loss regeneration process is slowed or even stopped, the bone repair is frequently required to stimulate bone regeneration through surgical insertion of materials(Fernandez et al., 2021). In recent decades, autograft materials have largely been used for bone repair due to their superior bone conduction, inducibility, and osteogenesis $(\mathrm{Ou}$ et al., 2020). In terms of bone healing, an autologous bone graft remains the therapy of choice in practical practice(Su et al., 2021). However, complications involved with the harvesting process and the limited volume of donor's bone limit the clinical applicability of this approach(Jeon et al., 2021). As a result, various bone substitutes, such as alternate graft materials, are critical for efficient bone restoration(Wang et al., 2021).

The radiographical findings in this study showed significant differences in BMD between the control group and all treated groups except group III and group IV which showed no significant differences at day 15. At the same time, on day 30 , there are significant differences in BMD among the control group, group I, group II and group V. ANOVA test showed no significant difference in group III and group IV. Group I showed minimum BMD while group V showed maximum BMD at all periods. This means that the ratio of combination at group $\mathrm{V}$ increased the bone formation compared to control, also showed that the ratio of combination at group $\mathrm{V}$ was more effective in bone formation than $\mathrm{CaCO}_{3}$ alone as in group I.

In this investigation, fresh bone development was seen at the peripheral 30days following surgery. This could be due to the osteoconductive qualities of eggshell $\mathrm{CaCO}_{3}$, which allow osteoprogenitor cells to adhere and move on the scaffolds, differentiate, and eventually produce new bone. These findings, which agree with the findings of other investigations, demonstrated that the proposed hydroxyapatite scaffold is suitable for bone tissue regeneration(Alhussary $\boldsymbol{e t}$ al., 2020; Wang et al., 2021). These findings concurred with the findings of other research, which said that hydroxyapatite (HA), which has exceptional mechanical qualities and outstanding osteoconductivity, should have a high potential for bone repair and regeneration(Zhu et al., 2021).

The healing process in defects filled with $\mathrm{CaCO}_{3}$ is heavily reliant on the material's osteoconductive characteristics. Studies have reported similar findings(Codrea et al., 2021). Again these findings agree with findings reported by Petrovova $\boldsymbol{e t}$ al. (2019) who mentioned that calcium carbonate scaffolds might represent a novel pattern in bone tissue engineering by encouraging osteogenesis as a means of mending bone defects and remodeling.
Ubiquinone is an antioxidant with free radical scavenging, membrane stabilizing, and cytoprotective properties(Dawood et al., 2020;Suárez-Rivero et al., 2021).In agreement with Li et al.(2019), Ubiquinone can stimulate osteogenic differentiation and increase the proliferation of bone marrow stromal cells (BMSCs) in a dose-dependent manner. While the antioxidant Ubiquinone plays a preventative and protective effect in osteoporosis by boosting osteoblastic bone production, decreasing osteoclastic bone resorption and oxidative stress, and avoiding cell senescence(Wu et al., 2021).

A study in rats found that short-term Ubiquinone administration reduced bone and mineral content loss caused by spinal cord damage, indicating that Ubiquinone had a favourable effect on BMD(Varela-López et al., 2017). The current study found that Ubiquinone's in vivo antioxidant activity may aid in the prevention of bone loss by lowering ROS levels in osteoclasts and osteoclast progenitor cells. This work supports Valentino et al. (2021) findings's who stated that Ubiquinone boosted matrix mineralization and Alkaline phosphatase (ALP) activity in murine osteoblast-like cells. The results from our study showed an increase in bone formation when using Ubiquinone alone or when combined with $\mathrm{CaCO}_{3}$. The ratio of bone formation will increase as the ratio of Ubiquinone increases. This may be due to the effect of Ubiquinone as an antioxidant.

\section{CONCLUSION}

The results of the current in vivo study demonstrate the high potential of the combination of eggshell calcium carbonate and Ubiquinone as basic components for bone regeneration and enhanced bone formation in mandibular defects in rabbits.

\section{ACKNOWLEDGMENT}

The authors are very grateful to the University of Mosul /College of Dentistry for their provided facilities, which improved the quality of this work.

\section{Declaration of Conflicting Interests}

The authors revealed that there was no potential conflicts of interest.

\section{REFERENCES}

ABDOLLAHIYAN, P., OROOJALIAN, F., HEJAZI, M., DE LA GUARDIA, M., \& MOKHTARZADEH, A. (2021). Nanotechnology, and scaffold implantation for the effective repair of injured organs: An overview on hard tissue engineering. Journal of controlled release, pp. 333, 391-417.

DOI.org/10.1016/j.jconrel.2021.04.003. 
AHIRWAR, L.K., KALRA, P., SHARMA, S., MOHAMED, A., MITTAL, R., DAS, S. AND BAGGA, B., 2021. Linezolid shows high safety and efficacy in the treatment of Pythium insidiosum keratitis in a rabbit model. Experimental Eye Research, 202, p.108345. DOI: 10.1016/j.exer.2020.108345. PMID: 33157127

AL-ABDALI, H.A., KAZANJI, M.N. AND TAQA, G.A., 2015. Effect of Incorporation of Calcium And Fluoride Salts on Transverse Strength of Acrylic Resin. AlRafidain Dental Journal, 15(1), pp.362-368. DOI: 10.33899/rden.2015.160869.

ALHUSSARY, B.N., A TAQA, G. AND TAQA, A.A.A., 2020. Preparation and characterization of natural nano hydroxyapatite from eggshell and seashell and its effect on bone healing. Journal of Applied Veterinary Sciences, 5(2), pp.25-32. DOI: 10.21608/JAVS.2020.85567.

ALI, Z. AND BHASKAR, S.B., 2016. Basic statistical tools in research and data analysis. Indian journal of anaesthesia, 60(9), p.662. DOI: 10.4103/00195049.190623

BARTH, J.G., (2020). Limestone and Calcium in Plants. Elemente der Naturwissenschaft, 112, pp.29-78. DOI: 10.18756/edn.112.29.

BIGHAM, A., FOROUGHI, F., GHOMI, E.R., RAFIENIA, M., NEISIANY, R.E. AND RAMAKRISHNA, S., 2020. The journey of multifunctional bone scaffolds fabricated from traditional toward modern techniques. Bio-Design and Manufacturing, pp.1-26. DOI:10.1007/s42242-020-000944.

CODREA, C.I., CROITORU, A.M., BACIU, C.C., MELINESCU, A., FICAI, D., FRUTH, V. AND FICAI, A., 2021. Advances in Osteoporotic Bone Tissue Engineering. Journal of Clinical Medicine, 10(2), p.253. DOI.org/10.3390/jcm10020253.

COLE, RAYMOND E., 2008. Improving clinical decisions for women at risk of osteoporosis: dual-femur bone mineral density testing. Journal of Osteopathic Medicine, 108(6), pp.289-295. DOI.org/10.7556/jaoa.2008.108.6.289.

DAWOOD, G.A., A TAQA, G. AND ALNEMA, M.M., 2020. Histological Effect Of Coq10 On Liver And Buccal Mucosa In Mice. Journal of Applied Veterinary Sciences, 5(2), pp.1-5. DOI: 10.21608/JAVS.2020.85543.

EL-GINDY, S., OBEID, M.F., ELBATOUTY, K.M., ELSHABOURY, E. AND HASSANIEN, E., 2021. Cell therapy: A potential solution for the healing of bone cavities. Heliyon, 7(1), p.e05885. DOI.org/10.1016/j.heliyon.2020.e05885.

FERNANDEZ-MEDINA, T. AND NANDA, A., 2021. Regeneration for Implant Dentistry. In Regenerative Approaches in Dentistry (pp. 133-150). DOI: 10.1007/978-3-030-59809-9_7.

FULLERTON, M., MCFARLĀND, R., TAYLOR, R.W. AND ALSTON, C.L., (2020). The genetic basis of isolated mitochondrial complex II deficiency. Molecular Genetics and Metabolism.131(1-2),pp.53-65. DOI: 10.1016/j.ymgme.2020.09.009.

HUNT, H.B., MILLER, N.A., HEMMERLING, K.J., KOGA, M., LOPEZ, K.A., TAYLOR, E.A.,
SELLMEYER, D.E., MOSELEY, K.F. AND DONNELLY, E., 2021. Bone Tissue Composition in Postmenopausal Women Varies With Glycemic Control From Normal Glucose Tolerance to Type 2 Diabetes Mellitus. Journal of Bone and Mineral Research, 36(2), pp.334-346. DOI: $10.1002 / j b m r .4186$.

ISA, Y.M., HARRIPERSADTH, C., MUSONGE, P., SAYAGO, A. AND MORALES, M.G., 2020. The application of eggshells and sugarcane bagasse as potential biomaterials in the removal of heavy metals from aqueous solutions. South African Journal of Chemical Engineering, 34(1), pp.142-150. DOI.org/10.1016/j.sajce.2020.08.002.

JEON, J.W., JANG, S., LEE, M.C. AND HAN, H.S., 2021. Faster bone union progression and less sclerosis at the osteotomy margin after medial opening-wedge high tibial osteotomy using highly porous $\beta$-tricalcium phosphate granules versus allogeneic bone chips: A matched case-control study. The Knee, 29, pp.33-41. DOI: 10.1016/j.knee.2021.01.017.

KNAPP-WILSON, A., PEREIRA, G.C., BUZZARD, E., RICHARDSON, A., COREY, R.A., NEAL, C., VERKADE, P., HALESTRAP, A.P., GOLD, V.A., KUWABARA, P. AND COLLINSON, I., (2021). Maintenance of Complex I and respiratory supercomplexes by NDUF-11 is essential for respiratory function, mitochondrial structure and health in $\mathrm{C}$. elegans. bioRxiv, pp.2021-01. DOI: https://DOI.org/10.1101/2021.01.06.425530.

KROUSOULOUDI, M. (2019) 'Investigation of human bone cells response deposited on different substrates to an electrical active environment'.pp15-21. (Doctoral dissertation). https://nemertes.lis.upatras.gr/jspui/bitstream/10889/12573/1/

LATTEY, K., QUINN, S. AND O'BRIEN, K., 2021. Overthe-counter antacids linked to severe hypokalaemia in the context of threatened preterm labour. BMJ Case Reports CP, 14(1), p.e236083. DOI: 10.1136/bcr-2020236083.

LI, X., ZHAN, J., HOU, Y., HOU, Y., CHEN, S., LUO, D., LUAN, J., WANG, L. AND LIN, D., 2019. Coenzyme Q10 regulation of apoptosis and oxidative stress in $\mathrm{H} 2 \mathrm{O} 2$ induced BMSC death by modulating the Nrf-2/NQO-1 signaling pathway and its application in a model of spinal cord injury. Oxidative Medicine and Cellular Longevity, 2019.p. 6493081. DOI.org/10.1155/2019/6493081.

LU, C., JIANG, W., WANG, H., JIANG, J., MA, Z. AND WANG, H., 2020. Computational Identification and Analysis of Ubiquinone-Binding Proteins. Cells, 9(2), p.520. DOI.org/10.3390/cells9020520.

OU, K.L., HOU, P.J., HUANG, B.H., CHOU, H.H., YANG, T.S., HUANG, C.F. AND UENO, T., 2020. Bone healing and regeneration potential in rabbit cortical defects using an innovative bioceramic bone graft substitute. Applied Sciences, 10(18), p.6239. DOI.org/10.3390/app10186239.

PETROVOVA, E., GIRETOVA, M., KVASIlOVA, A., BENADA, O., DANKO, J., MEDVECKY, L. AND SEDMERA, D., 2019. Preclinical alternative model for analysis of porous scaffold biocompatibility in bone tissue engineering. ALTEX-Alternatives to animal 
experimentation, 36(1),
DOI.org/10.14573/altex.1807241.

SU, B., TANG, K., LIU, W., LUO, X., QUAN, Z., JIANG, D. AND PENG, X., 2021. One-stage posterior debridement, autogenous spinous process bone graft and instrumentation for single segment lumbar pyogenic spondylitis. Scientific Reports, 11(1), pp.1-8. DOI.org/10.1038/s41598-021-82695-2.

SUÁREZ-RIVERO, J.M., PASTOR-MALDONADO, C.J., POVEA-CABELLO, S., ÁLVAREZCÓRDOBA， M., VILLALÓN-GARCÍA， I., MUNUERA-CABEZA, M., SUÁREZ-CARRILLO, A., TALAVERÓN-REY, M. AND SÁNCHEZALCÁZAR, J.A., 2021. Coenzyme Q10 Analogues: Benefits and Challenges for Therapeutics. Antioxidants, 10(2), p.236. DOI.org/10.3390/antiox10020236.

TANEJA, P., MESHRAMKAR, R. AND GUTTAL, K.S., 2015. Assessment of bone mineral density in pre-and post-menopausal women using densitometric software: A pilot study. Journal of Interdisciplinary Dentistry, 5(3), p.125. DOI: $10.4103 / 2229-5194.181374$.

VALENTINO, A., DI CRISTO, F., BOSETTI, M., AMAGHNOUJE, A., BOUSTA, D., CONTE, R. AND CALARCO, A., 2021. Bioactivity and Delivery Strategies of Phytochemical Compounds in Bone Tissue Regeneration. Applied Sciences, 11(11), p.5122. DOI.org/10.3390/app11115122.

VARELA-LÓPEZ, A., OCHOA, J.J., LLAMASELVIRA, J.M., LÓPEZ-FRÍAS, M., PLANELLS, E., RAMIREZ-TORTOSA, M., RAMIREZ-TORTOSA, C.L., GIAMPIERI, F., BATTINO, M. AND QUILES, J.L., 2017. Age-related loss in bone mineral density of rats fed lifelong on a fish oil-based diet is avoided by coenzyme Q10 addition. Nutrients, 9(2), p.176. DOI:10.3390/nu9020176.

WALSH, L.J. AND HOSSEINPOUR, S., 2021. The Paradigm of Regenerative Dentistry and Its Future Perspectives. In Regenerative Approaches in Dentistry (pp. 1-8). DOI: 10.1007/978-3-030-59809-9.

WANG, M., ZHANG, X., LI, Y. AND MO, A., 2021a. The Influence of Different Guided Bone Regeneration Procedures on the Contour of Bone Graft after Wound Closure: A Retrospective Cohort Study. Materials, 14(3), p.583. DOI.org/10.3390/ma14030583.

WANG, W., LIPARULO, I., RIZZARDI, N., BOLIGNANO, P., CALONGHI, N., BERGAMINI, C. AND FATO, R., 2021b. Coenzyme Q depletion reshapes MCF-7 cells metabolism. International Journal of Molecular Sciences, 22(1), p.198. DOI.org/10.3390/ijms22010198

WU, X., LIANG, S., ZHU, X., WU, X. AND DONG, Z., 2021. CoQ10 suppression of oxidative stress and cell senescence increases bone mass in orchiectomized mice. American journal of translational research, 13(4), p.3923.

https://www.ncbi.nlm.nih.gov/pmc/articles/PMC8129264/

ZHU, G., ZHANG, T., CHEN, M., YAO, K., HUANG, X., ZHANG, B., LI, Y., LIU, J., WANG, Y. AND ZHAO, Z., 2021. Bone physiological microenvironment and healing mechanism: Basis for future bone-tissue engineering scaffolds. Bioactive materials, 6(11), pp.4110-4140.

DOI.org/10.1016/j.bioactmat.2021.03.043.
How to cite this article:

Ahmed A. Hussein and Ghada A. Taqa, 2021.

The impact of natural calcium carbonate and Ubiquinone on bone mineral density in rabbits. Journal of Applied Veterinary Sciences, 6 (4): 15 - 22. DOI:https://dx.doi.org/10.21608/javs.2021.87062.1091 